\title{
Perencanaan dan Pengelolaan Pesantren Daarul Abror Melalui Pengembangan Kurikulum PAI
}

\author{
Dwi Saprida Ramami ${ }^{1}$, Suparta ${ }^{2}$, Andi Arif Rifa' ${ }^{3}$ \\ ${ }^{12}$ Pascasarjana, ${ }^{3}$ Fakultas Tarbiyah \\ IAIN Syaikh Abdurrahman Siddik Bangka Belitung, Indonesia \\ Idwi280975@yshoo.com, 2partasuparta23@yahoo.co.id, 3andiarifrifai@gmail.com
}

\begin{abstract}
This study reports on the planning and management of Islamic Boarding School Daarul Abror in developing curriculum of Islamic Education Subject. This study attempts to address the following question; (1) How is the administration management at Islamic Boarding School Daarul Abror? (2) How are the development and implementation Islamic Education Subject at Islamic Boarding School Daarul Abror? It is conducted at Islamic Boarding School Daarul Abror Bangka, Bangka Belitung Islands Province. The data for the study are obtained through two instruments; The interview and observation. The interview is conducted to obtain the clarification and expanation from the boarding school. The observation is done during the interaction in the teaching learning process to observe the activities done in the school. The subject of this study is the vice-head master of the school who has been a teacher as well as curriculum developer in the Islamic Boarding School. The finding reveal that, (1) the administration management at Islamic Boarding School Daarul Abror is conducted based on the educational institutions of the Ministri of Religious Affair and the Ministri of Education and Culture Republic Indonesia. (2) the development of and the implementation of Islamic Education subjetcs is by applying education in a classroom as well as out of classroom refering to the achievement life skill and the Islamic character building in dayly life. Based on the finding it is recommended that the stakeholders of the Islamic Boarding School should keep managing their institution to develope and applying nowdays educational system.
\end{abstract}

Keywords: Curriculum Management PAI, Pesantren, Daarul abror

\begin{abstract}
Abstrak
Penelitian ini menggali tentang perencanaan dan pengelolaan pesantren Daarul Abror melalui pengembangan kurikulum Pendidikan Agama Islam. Penelitian ini mengacu pada
\end{abstract}


permasalahan sebagai berikut; (1) Bagaimana pengelolan administrasi pada pesantren Darul Abror? (2) Bagaimana pengembangan dan pelaksanaan kurikulum di Pesantren Darul Abror? Penelitian ini dilaksanakan di pondok pesanren Daarul Abror Bangka, Provinsi Bangka Belitung. Pengambilan data dalam penelitian ini menggunakan dua instrume; interview dan observation. Interview dilakukan untuk memperoleh penjelasan dari pihak pengelola pesantren. Observasi dilakukan melalui pengamatan pada saat proses belajar mengajar. Subjek dari penelitian ini adalah wakil kepala madrasah bidang kurikulum yang sudah lama menjadi guru pada dan tim pengembang kurikulum di pondok pesantren tersebut. Penemuan dari penelitian ini menunjukkan bahwa; (1) managemen administrasi pada pondok pesantren Daarul Abror dilaksanakan dengan mengacu kepada mata pelajaran yang ada pada kementerian Agama dan Kementerian Pendidikan dan Kebudayaan Republik Indonesia. (2) implemantasi pengembanngan kurikulum pada mata pelajaran Pendidikan Agama Islam dilaksanakan di dalam kelas dan di luar kelas dalam rangka pembelajaran kecakapan hidup dan penerapan karakter Islam dalam kehidupan sehari-hari. Berdasarkan penemuan di atas penulis merekomendasikan bahwa para stakeholders di pondok pesantren harus terus mengarahan lembaganya untuk berkembang dan menerapkansistem pembelajaran kekinian.

Kata Kunci: Managemen Kurikulum PAI, Pesantren, Daarul Abrol

\section{A. Pendahuluan}

Perubahan kurikulum yang terjadi di Indonesia dewasa ini salah satu diantaranya adalah karena ilmu pengetahuan itu sendiri selalu dinamis. Selain itu, perubahan tersebut juga dinilainya dipengaruhi oleh kebutuhan manusia yang selalu berubah juga pengaruh dari luar, dimana secara menyeluruh kurikulum itu tidak berdiri sendiri, tetapi dipengaruhi oleh perubahan iklim ekonomi, politik, dan kebudayaan. Sehingga dengan adanya perubahan kurikulum itu, pada gilirannya berdampak pada kemajuan bangsa dan negara. Kurikulum pendidikan harus berubah tapi diiringi juga dengan perubahan dari seluruh masyarakat di Indonesia yang harus mengikuti perubahan tersebut. Dimana fungsi dari kurikulum itu sendiri sebagai pedoman untuk mengatur kegiatan di sekolah/madrasah serta sebagai alat untuk mencapai tujuan suatu lembaga. ${ }^{1}$

Indonesia telah berusaha meningkatkan mutu pendidikan pada semua jenjang pendidikan tetapi usaha tersebut masih banyak mengalami kendala, terutama dalam upaya peningkatan mutu pendidikan di sekolah. Peningkatan mutu pendidikan di sekolah sangat

${ }^{1}$ Suparta, Pengantar Teori Dan Aplikasi Pengembangan Kurikulum PAI, 1st ed. (Jakarta: Rajawali pers, 2016). 
terkait dengan upaya perbaikan. Perbaikan tersebut dilakukan dalam bentuk pembaharuan kurikulum disesuaikan dengan perkembangan dunia Global. Seperti pergantian dari kurikulum 1994 yang berbasis materi diganti dengan kurikulum 2004 atau KBK (Kurikulum Berbasis Kompetensi) yang berorientasi pada pencapaian-pencapaian kompetensi kemudian berganti dengan KTSP pada tahun 2006 untuk merespon keputusan pemerintah tentang otonomi pendidikan dan setelah itu dirubah lagi dengan Kurikulum 2013 yang kemudian kurikulum 2013 di revisi kembali dimana karakter peserta didik lebih di tonjolkan.

Madrasah berbeda dengan sekolah umum, dimadrasah biasanya ketika murid bertemu dengan guru atau sesama teman mengucapkan salam (assalamualaikum), berbeda dengan sekolah ketika seorang murid bertemu dengan guru atau sesama biasanya kata sapa yang mereka ucapkan bukanlah salam dalam bentuk bahasa Arab melainkan bahasa seharihari seperti selamat pagi, selamat siang dan sampai jumpa. Di madrasah pelajaran agama Islam lebih dominan dan lebih mengutamakan pelajaran agama Islam walaupun pelajaran umumpun dipelajari, hal ini untuk menyeimbangkan antara ilmu agama sebagai corak dan madrasah sebagai sekolah umum, sedangkan di sekolah umum pelajaran agama Islam biasanya dijadikan satu dengan durasi waktu yang sangat singkat dalam seminggu hanya satu atau dua jam dan lebih fokus pada pelajaran ilmu umum. Inilah salah satu perbedaan yang nampak antara kedua lembaga tersebut, sehingga dalam penerapan kurikulumnya pun berbeda pula walaupun harus disesuaikan dengan standar pendidikan nasional termasuk kurikulumnya.

Pesantren sebagai lembaga pendidikan keagamaan menjadi tren sekarang ini, setidaknya peminat pesantren dari tahun ke tahun mengalami peningkatan ini tentu bukan tanpa sebab, menejemen pengelolaan dan kurikulum yang bisa diterima masyarakat tentu menjadi rujukan bagi masyarakat untuk memilih pesantren sebagai tempat anak - anak mereka dididik, berdasarkan pengamatan penulis peminat pesantren dari kalangan ekonomi menengah ke atas. Selain kurikulum yang di nilai luwes pesantren juga di lihat mempunyai keunikan dalam pengajaran dan penyajian materinya kepada para santrinya, biasanya pengajian bisa berbentuk kuliah terbuka dan penyajian yang bersipat aplikatif. ${ }^{2}$

\footnotetext{
Aksara, 2001).
}

${ }^{2}$ KH Abdurrahman Wahid, Menggerakkan Tradisi; Esai-Esai Pesantren (LKIS Pelangi 
Pesantren dalam pengelolaan berbeda-beda, setiap pondok pesantren mempunyai visi dan misi yang berbeda dalam mengelolah lembaganya, untuk itu setiap pondok pesantren harus mempunyai stratrategi untuk mengantisipasi keadaan luar yang berdampak terhadap lembaganya ${ }^{3}$. Adapun rumusan Masalah dalam riset ini adalah 1) bagaimana pengelolan administrasi pada pesantren Darul Abror, 2) Bagaimana pengembangan dan pelaksanaan kurikulum di Pesantren Darul Abror.

\section{B. Literature Review}

Melalui penelusuran penulis terhadap beberapa penelitian yang hampir sama dengan yang penulis teliti diantaranya:

Pertama, penelitian Abdul khamid yang berjudul "Manajemen pondok pesantren Nurul Amal desa Kenteng kecamatan Bandungan Kabupaten Semarang”. Penelitian ini untuk mengetahui pelaksanaan manajemen pesantren di Nurul Amal yang dilaksanakan pondok pesantren tersebut yaitu apa yang mendukung dan menghambat pelaksanaan manajemennya. Metode penelitian dilaksanakan dengan metode kualitatif, pengumpulan data di lakukan dengan cara observasi, wawacara dan study dokumentasi. Hasil penelitian menunjukan bahwa manajemen di pondok pesantren Nurul Amal telah dilakukan dengan baik melalui perencanaan, pengorganisasian, pengerak dan pengawasan. ${ }^{4}$

Penelitian diatas untuk mengetahui hal-hal yang mendukung serta menghambat manajemen pesantren sementara yang penulis teliti lebih kepada pada pengelolaan dan pengembangan kurikulum pendidikan agama Islamnya.

Kedua, penelitian yang dilakukan oleh Nur Eka Setiawati yang berjudul “Manajemen pembiayaan pendidikan pondok pesantren dan lembaga pendidikan terpadu Nurrushiddiq Cirebon. Penelitian ini dilakukan dengan cara mengumpulkan informasi tentang perencanaan, pengorganisasian, pelaksanaan pengalian alokasi dan akuntabilatas pembiayaan pendidikan pesantren Nurrushiddiq, metode penelitian dilakukan dengan cara kualitatif, temuan dalam penelitian ini menunjukkan bahwa manajemen pembiayaan di

\footnotetext{
${ }^{3}$ Abd Halim, Manajemen Pesantren (Pustaka Pesantren, 2005).

${ }^{4}$ Abdul Khamid and Linda Istiroh, "Manajemen Pondok Pesantren Nurul Amal Desa Kenteng Kecamatan Bandungan Kabupaten Semarang," n.d.
} 
pondok pesantren Nurrusiddiq telah dilaksanakan dengan baik, walaupun belum ada juknis yang baku sebagai standar untuk pesantren. ${ }^{5}$

Berbeda dengan penelitian penulis, dimana pada penelitian tersebut fokus ke manajemen pembiayaan sedangkan yang penulis teliti lebih kepada pengembangan kurikulum pendidikan agama Islam dan pengelolaan administrasi pada pondok pesantren.

Ketiga penelitian Laikal Muktifah yang berjudul, "Pola pengembangan kurikulum pesantren” untuk mengetahui pola pengembangan kurikulum pesantren Al-Mukhlishin yang dilakukan dengan metode wawancara, observasi dan study dokumentasi, dari observasi yang dilakukan menunjukkan sistem kurikulum dan pendidikan di pondok pesantren Al-Mukhlishin mengintegrasikan kurikulum dari pemerintah dalam hal ini kementerian agama dan kurikulum non formal melalui pengajian kitab kuning yang bertingkat (Ula, wustha,'ulya). Pengembangan diri pada pesantren ini dilakukan dalam bentuk memberikan pembelajaran berupa pidato dan khatib dengan 3 bahasa yaitu Arab, Inggris, dan Indonesia. ${ }^{6}$

Penelitian ini hampir sama dengan penelitian yang penulis lakukan tapi bereda tempat dan lebih kongkrit lagi penelitian yang penulis lakukan lebih melihat pengolahan dan perencanaan kurikulum pendidikan agama islam pada pesantren.

\section{Metode Penelitian}

Penelitian ini di susun dengan metode descriptive kualitatif, yaitu dengan mengambil data - data tertulis dari orang - orang yang di amati.Metode descritive adalah metode yang mengkaji bentuk - bentuk aktivitas, karekterisitik, perubahan berupah katakata sehingga bisa menentukan persamaan dan perbedaan dengan penomena yang lainya, dengan metode kualitatif di harapkan mudah memahami suatu peristiwa, tingkah laku manusia dalam situasi tertentu yang bertujuan untuk memahami object lebih mendalam ${ }^{7}$.

Dalam hal ini penulis melakukan penelitian terhadap pesantren Daarul Abror yang berada di desa Kace Mendoa Barat Kabupaten Bangka Propinsi Kepulauan Bangka

\footnotetext{
${ }^{5}$ Nur Eka Setiowati, "Manajemen Pembiayaan Pendidikan Pondok Pesantren Dan Lembaga Pendidikan Terpadu Nurushiddiiq Cirebon," Al-Amwal: Jurnal Ekonomi Dan Perbankan Syari'ah 7, no. 2 (2016).

${ }^{6}$ Lailial Muhtifah, "Pola Pengembangan Kurikulum Pesantren Kasus Al-Mukhlishin Mempawah Kalimantan Barat," Jurnal Pendidikan Islam UIN Sunan Gunung Djati 27, no. 2 (2012): 203-22.

${ }^{7}$ Imam Gunawan, “Metode Penelitian Kualitatif,” Jakarta: Bumi Aksara, 2013.
} 
Belitung, baik data yang berupa pengamatan maupun data yang melalui hasil wawancara kepada narasumber yang terkait. Teknik pengumpulan data dengan menggunakan Natural Approach, maka penulis mengambil dengan 3 teknik yaitu, observasi, wawancara, dan dokumentasi.

\section{Pembahasan}

1. Pengembangan Kurikulum PAI di Pesantren

Perubahan - perubahan yang terjadi pada dunia pendidikan tentu nya dengan tujuan untuk memperbaiki mutu pendidikan itu sendiri, pendidikan Islam yang berdasarkan pada tuntunan agama Islam bertujuan untuk menjadikan manusia beriman, bertaqwa dan berakhlak mulai. Perkembangan kurikulum pendidikan nasional dari masa ke masa tentu berdampak pula dengan kurikulum pendidikan agama Islam, hal ini tentu membuat para pendidik berpikir keras untuk bisa menyesuaikan dengan perkembangan zaman.

Perkembangan Pendidikan Agama Islam itu sendiri banyak sekali mengalami kendala khususnya pada zaman penjajahan baik pada masa penjajahan Belanda maupun penjajahan Jepang, walaupun pada masak penjajahan Jepang sedikit banyak ada lebih memberikan peluang yang membuat kedudakan Islam menjadi lebih maju ${ }^{8}$.

Beberapa kebijakan dalam perkembangan kurikulum pendidikan Agama Islam setelah zaman penjajahan diantara :

a. Kebijakan kurikulum di masa orde lama, pada masa ini pendidikan agama Islam menjadi dualism karena di serahkan pada 2 menteri yaitu menteri pendidikan dan menteri Agama

b. Kebijakan kurikulum di masa Orde baru, pada masa ini kurikulum pendidikan agama Islam telah berkembang dengan pesat dan para tokoh Ulama dengan leluasa menyebarkan agama Islam pendidikan formal maupun informal

c. Kebijakan pendidikan agama Islama pada masa reformasi, pada masa reformasi masih masyarakat menyadari bahwa pendidikan di Indonesia masih sangat jauh tertinggal, disinilah kemudian di diadakannya reformasi di bidang pendidikan dan pemerintah menggangap perlu pendidikan mental dan spiritual. ${ }^{9}$

${ }^{8}$ Suparta, Pengantar Teori Dan Aplikasi Pengembangan Kurikulum PAI.

${ }^{9}$ Suparta. 
2. Perencanaan dan Pengolahan Manajemen Adminitrasi di Pesantren Daarul Abror

Sebelum membahas apa itu manajemen pesantren maka kita harus tahu dahulu apa itu sistem manajemen dan apa itu pesantren. Sistem adalah cara, sarana, upaya, dan organ. ${ }^{10}$ Dan manejemen berasal dari bahasa Inggris yaitu management artinya yang dikembangkan dari kata to manage, yang artinya mengatur atau mengelola. Kata manage itu sendiri berasal dari Italia Maneggio yang diadopsi dari bahasa latin managiare, yang berasal dari kata manus yang artinya tangan. ${ }^{11}$ Dalam bahasa Arab berasal dari nazhoma atau idarah artinya yang menata beberapa hal dan mengabungkan beberapa antara satu dengan yang lain. ${ }^{12}$

Permasalahan seputar pengelolaan model pendidikan pondok pesantren dalam hubungannya dengan peningkatan kualitas sumberdaya manusia (human resource) merupakaan berita aktual dalam arus perbincangan kepesantrenan kontemporer karena pesantren dewasa ini dinilai kurang mampu mengoptimalkan potensi yang dimilikinya namun meskipun demikian setidaknya terdapat dua potensi besar yang dimiliki pesantren yaitu: (1) Potensi Pendidikan dan (2) Penggembangan masyarakat.

Sejalan dengan penyelenggaraan pendidikan formal beberapa pesantren menggalami penggembanggan pada aspek manajemen, organisasi, dan atministrasi penggelolan keuangan. Perkembangan ini dimulai dari perubahan gaya kepemimpinan pesantren dari karismatik ke rasionalostik, dari otoriter paternalistic ke diplomatik partisipatif.

Beberapa pesantren sudah membentuk badan pengurus harian sebagai lembaga payung yang khusus mengelola dan menanggani kegiatan-kegiatan pesantren misalnya pendidikan formal, diniyah, penggajian majelis ta'lim, sampai pada masalah pengginapan (asrama santri), kerumah tanggan, kehumasan. Pada tipe pesantren ini pembagian kerja antar unit sudah perjalan denggan baik, meskipun tetap saja kyai memiliki pengaruh yang kuat. $^{13}$

Sayangnya perkembangan tersebut tidak merata di semua pesantren. Secara umum pesantren masih menghadapi kendala serius menyangkut ketersediaan sumber daya

\footnotetext{
${ }^{10}$ Halim, Manajemen Pesantren.

${ }^{11}$ Zamakhsyari Dhofier, Tradisi Pesantren, 8th ed. (Jakarta: LPEES, 2011).

${ }^{12}$ Amin dan Ishom El -saha Haedari, Peningkatan Mutu Perpadu Pesanten Dan Madrasah Diniyah (Jakarta: Diva Pustaka, 2008).

${ }^{13}$ Dhofier, Tradisi Pesantren.
} 
manusia profesional dan penerapan manajemen yang umumnya masih konvensional, misalnya tiadanya pemisahan yang jelas antara yayasan, pimpinan madrasah, guru dan staf atministrasi, tidak adanya transparasi pengelolaan sumber-sumber keuangan belum terdistribusinya pengelolaan pendidikan, dan banyaknya penyelenggaraan atministrasi yang tidak sesuai aturan baku organisasi. Kyai masih merupakaan figure sentral dan penentu kebijakan pendidikan pesantren. ${ }^{14}$

Rekuitmen ustadz atau guru, penggembangan akademik, reward sistem, bobot kerja juga tidak berdasarkan aturan yang berlaku. Penyelenggaraan pendidikan sering kali tanpa perencanaan. Berapa banyak pesantren yang memiliki rencana induk pengembangan (RIP), dan statutnya misalnya sebagai pedoman penggelolaan pendidikan.

Kerumitan dan permasalahan ini menyebapkan antara normativitas dan kondisi opyektif pesantren ada kesenjangan termasuk dalam penerapan teori manajemen pendidikan. Semata-mata berpegang pda normativitas dengan mengabaikan kondisi obyektif yang terjadi di pesantren adalah tindakan kurang bujaksana, kalau tidak dikatakan gagal memahami pesantren. Akan tetapi membiarkan kondisi itu berjalan terus tanpa ada pembenahan juga tidak arif. Penerapan manajemen pendidikan tidak hanya di tetapkan tanpa mempertimbangkan atau mengakomodasi keadan yng riil di pesantren. Harus ada toleransi dalam menyikapi kesenjangan itu secara wajar tanpa menggundang konflik.

Seiring dengan pengelolaan kurikulum yang ada berdasarkan hasil wawancara yang dilakukan terungkap bahwa kurikulum yang diterapkan di pesantren Daarul Abror merupakan perpaduan antara kurikulum yang di terapkan di Pesantren Gontor Jawa Timur kurikulum Kementerian Agama, dan kurikulum Kementerian Pendidikan dan Kebudayaan.

Penggabungan model kurikulum lajim terjadi pada sebuah lembaga pendidikan tidak terkecuali pada lembaga pendidikan pesantren. Pola seperti ini biasanya dilakukan untuk mewujudkan harapan ideal masyarakat tentang proses kegiatan pembelajaran, pembiasaan kehidupan sehari hari, dan hasil belajar yang diharapkan sehingga kurikulum yang di terapkan bisa mengakomodir kebutuhan wali santri dan santri itu sendiri.

Menurut Tyler ada 4 tahap yang harus dilakukan dalam pengembangan kurikulum yang meliputi: (1) Menentukan tujuan pendidikan, (2)Menentukan proses pembelajaran yang harus dilakukan, (3) Menentukan organisasi pengalaman belajar, dan (4) Menentukan

\footnotetext{
${ }^{14}$ Dhofier.
} 
evaluasi pembelajaran. Keempat tahap pengembangan kurikulum tersebut hendaknya menjadi satu kesatuan tindakan yang harus dilakukan oleh sebuah lembaga pendidikan.

Stakeholders dilibatkan dalam penetapan perubahan kurikulum di pesantren ini dan bukan hanya keputusan pimpinan pondok pesantren saja. Hal ini penting dilakukan mengingat stakeholders merupakan rangkaian komponeN dalam sebuah lembaga pendidikan yang memiliki peran yang sangat menentukan dalam menentukan arah dan tujuan lembaga. Mereka adalah pemegang atau pemangku kebijakan. Mereka bisa orang perorangatau sekelompok orang yang memiliki kepentingan atau tanggung jawab terhadap pendidikan. Hal ini sejalan dengan pengertian stakeholders menurut Tia Aulia (2014) yang mengatakan bahwa stakeholders adalah orang-orang atau badan yang berkepentingan langsung maupun tidak langsung yang bertanggung jawab terhadap pengelolaan sebuah lembaga pendidikan. ${ }^{15}$

Pola pengembangan kurikulum yang dilakukan di pesantren Daarul Abror dilaksanakan dengan menyesuaikan tuntutan dunia pendidikan modern saat ini. Kesadaran stakeholders akan tuntutan pendidikan kekinian ternyata sudah disadari dan dipahami oleh mereka bahwa sudah semestinya pendidikan mengalami perubahan, sebab proses pendidikan yang tidak sejalan dengan tuntutan perkembangan zaman akan membuat manusia stagnan (jumud). Sebagaimana di sampaikan oleh Lihin (2019) bahwa pendidikan modern adalah pendidikan dengan menerapkan prinsip-prinsip belajar yang sesuai dengan tuntutan kekinian, sehingga dapat dipersiapkan anak didik pada masanya. ${ }^{16}$

Semua muatan kurikulum yang ada juga dikembangkan menyesuaikan dengan tuntutan dunia moderen bukan hanya pada muatan kurikulum mata pelajaran umun melainkan juga mata pelajaran Pendidikan Agama Islam dimana pola pengembangan Pendidikan Agama Islam mengacu kepada pola pengembangan pada pesantren moderen. Kebutuhan akan penerapan pengembangan kurikulum sesuai dengan era moderen saat menjadi kebutuhan semua lembaga pendidikan di pesantren dimana pesantren setidaknya menurut Abdullah Syukri Zarkasyi (ada empat pola pendidikan dan pengajarannya, yaitu;

15 Tia Aulia, "Stakeholders Pendidikan,"

https://huurinien.blogspot.com/2015/09/stakeholder-dalam-pendidikan.html, 2014.

${ }^{16}$ Lihin, "Pengertian Pendidikan Moderen," n.d. 
1. learning to know/think. Belajar yang bersifat teoritis dan berorientasi pada pengetahuan rasional dan logis adalah sesuatu yang menyatu dalam pendidikan pesantren.

2. learning to do. Belajar untuk melakukan atau berbuat sesuatu. Pola ini dilakukan melalui pembekalan santri dengan ketrampilan-ketrampilan yang dapat membantunya menyelesaikan persoalan-persoalan keseharian yang dihadapinya. Dalam membangun kemandirian para santri.

3. Learning to live together. Pendidikan ini bermaksud menanamkan kesadaran bahwa kita hidup dalam sebuah masyarakat global dengan aneka ragam latar belakang sosial, budaya, bahasa, suku, bangsa, dan agama.

4. Learning to be. Semangat sangat kental hubungannya dengan dunia pesantren. Karena belajar berarti belajar menjadi diri sendiri yang pada intinya adalah pendidikan untuk membentuk sosok pribadi yang berakhlakul karimah. ${ }^{17}$

Landasan atau dasar pengembangan kurikulum dalam memperkuat karakter lembaga pesantren Daarul Abror mereka mengacu BNSP, Direktorat Pendidikan Madrasah, dan Direktorat PENDIS Kementerian Agama RI dengan Kekhasan lembaga yang disesuaikan dengan masyarakat moderen sekarang ini. Ini berarti pesantren Daarul Abror sebagaimana memilah landasan pengembangan kurikulumnya dimana untuk jenjang SLTP mengacu kepada DIKNAS dengan pola SMP dan untuk jenjang SLTA mengacu kepada Kemenang Bidang Pendidikan Madrasah dengan pola MA.

2. Pengembangan dan Pelaksanaan kurikulum di Pesantren Daarul Abrol

Dengan melibatkan seluruh stakeholders pengembangan komponen kurikulum yang dikembangkan di pesantren Daarul Abror adalah komponen materi pelajaran dan komponen Media pembelajaran. Komponen materi pelajaran sangat perlu untuk dikembangkan sebab secara umum sudah ada standar dari pemerintah tetapi lembaga pesantren msih sangat perlu untuk aktif dalam mengembangkan materi pembelajaran Pendidikan Agama Islam. Penambahan-penambahan materi pembelajan pun terjadi dalam proses pembelajaran di luar kelas yaitu dalam kegiatan pembelajaran pesantren secara khusus bahkan dengan menggunakan kitab-kitab rujukan dan buku-buku khas pesantren.

${ }^{17}$ Abidullah, "Penilaian Pembelajaran,” https://abibulah.blogspot.com/2013/04/penilaianpembelajaran.html, 2013. 
Sedangkan pengembangan media pembelajaran dilakukan dengan pengadaan dan pengembangan oleh pihak guru mata pelajaran dan pihak pesantren. Secara umum sudah ada standar kurikulum dari pemerintah tetapi lembaga pesantren aktif dalam mengembangkan materi pembelajaran pendidikan agama Islam. Penambahan-penambahan materi pembelajan pun terjadi dalam proses pembelajaran di luar kelas yaitu dalam kegiatan pembelajaran pesantren secara khusus malahan dengan menggunakan kitab-kitab rujukan dan buku-buku asli baik dan para pendidiknya mengembangkan metode-metode pembelajaran yang aktif yang meningkatkan motivasi pembelajaran peserta didik.

Dengan sistem pendidikan berasrama pesantren memiliki kesempatan luas untuk mengembangkan konsep pembelajaran yang mendukung terhadap proses pembelajaran pendidikan agama Islam dengan proses pembelajaran di luar kelas dan kegiatan-kegiatan yang mendukung.Pesantren yang moderen dianggap mampu untuk mencetak para santri dalam memahami, menghayati, dan mengamalkan pendidikan agama Islam karena pada dasarnya pendidikan agama Islam itu merupakan pendidikan yang mengajarkan budi pekerti dan akhlak mulia.

Konsep pembelajaran pendidikan agama Islam yang diterapkan di pesantren Daarul Abror meliputi pembahasan tentang Pendekatan, Model, Strategi, Metode, dan Teknik pembelajaran untuk mencapai pengembangan tiga ranah (Affektif, Psycomotor, dan Kogniitif). Dasar filosofis dari pengembangan proses pembelajaran mengacu pada hakikat pembelajaran itu sendiri.

Hakekat dari proses pengembangan kurikulum pembelajaran menurut Dadang Gani meliputi; Pertama, proses pembelajaran adalah proses yang kompleks, interaktif, dan dinamis. Kesiapan guru mata pelajaran untuk mengenal karaktersitik peserta didik dalam pembelajaran merupakan modal utama penyampaian bahan belajar dan menjadi indikator susksesnya pelaksanaan pembelajaran. ${ }^{18}$

Kedua, proses pembelajaran yang terencana diarahkan untuk mewujudkan suasana belajar dan proses pembelajaran yang kondusip, hal ini berarti tidak boleh mengesampingkan proses belajar itu sendiri. Pembelajaran tidak semata mata berusaha untuk mencapai hasil belajar akan tetapi bagaimana proses belajar yang terjadi.

${ }^{18}$ Dadang Gani, "Kajian Pembelajaran Islam Di Pesantren Modern," https://dadanggani.blogspot.com/2010/04/kajian-pembelajaran-agama-islam-di.html., 2010. 
Ketiga, suasana belajar dan pembelajaran itu diarahkan agar pesera didik dapat mengembangkan potensi dirinya, ini berarti proses pembelajaran yang diterapkan harus berorientasi kepada siswa. Proses pembelajaranharus diupayakan untuk pengembangan potensi anak didik, dengan demikian anak harus dipandang sebagai manusia yang sedang berkembang dan memiliki potensi.

Keempat, akhir dari proses pendidikan adalah kemampuan anak memiliki kekuatan spiritual keagamaan, pengendalian diri, kepribadian, kecerdasan, akhlak mulia, dan keterampilan yang diperlukan dirinya, masyarakat, Bangsa dan Negara. Ujung dari proses pendidikan adalah pembentukan sikap, pengembangan kecerdasan atau intelektual serta pengembangan keterampilan anak sesuai dengan kebutuhan mereka.

Kendala dalam implementasi kurikulum di pesantren Daarul Abror adalah mengenai aspek penilaian.Kendala penilaian atau evaluasi ini memeng yang paling sering dirasakan sebab evaluasi atau penilaian dalam pengajaran tidak semata mata dilakukan terhadap hasil belajar siswa tetapi juga harus dilakukan terhadap proses pengajaran itu sendiri. Penilaian terhadap hasil belajar siswa harus bisa merefleksikan penilaian terhadap pengajaran itu sendiri.

Evaluasi pengajaran merupakan suatu komponen dalam sistem pengajaran, sedangkan sistem pengajaran merupakan bentuk implementasi dari kurikulum sebagai upaya untuk menciptakan proses belajar mengajar di kelas. Menurut Abibullah ,fungsi utama evaluasi di dalam kelas adalah untuk menentukan hasil-hasil dari rangkaian pengajaran. Hasil-hasil yang dicapai dari proses pengajaran tersebut mengindikasikan capaian dari target atau tujuan pembelajaran yang di rancang oleh pengajar. Oleh karena itu, prinsip-prinsip evaluasi memegang peranan penting dalam sebuah rancangan pengembangan kurikulum. ${ }^{19}$

Perubahan kurikulum pendidikan di Indonesia berpengaruh pada perkembangan prinsip penilaian pendidikan. Oleh karena itu prinsip penilaian dijelaskan lebih lanjut dalam Peraturan Menteri Pendidikan dan Kebudayaan Republik Indonesia Nomor 66 Tahun 2013. Penilaian hasil belajar peserta didik pada jenjang pendidikan dasar dan menengah didasarkan pada prinsip-prinsip sebagai berikut;

${ }^{19}$ Abidullah, "Penilaian Pembelajaran." 
a. Objektif, berarti penilaian berbasis pada standardan tidak dipengaruhi faktor subjektivitas penilai.

b. Terpadu, berarti penilaian oleh pendidik dilakukan secara terencana, menyatu dengan kegiatan pembelajaran, dan berkesinambungan.

c. Ekonomis, berarti penilaian yang efisien dan efektif dalam perencanaan, pelaksanaan, dan pelaporannya.

d. Transparan, berarti prosedur penilaian, kriteria penilaian, dan dasar pengambilan keputusan dapat diakses oleh semua pihak.

e. Akuntabel, berarti penilaian dapat dipertanggungjawabkan kepada pihak internal sekolah maupun eksternal untuk aspek teknik, prosedur, dan hasilnya.

f. Edukatif, berarti mendidik dan memotivasi peserta didik dan guru. ${ }^{20}$

\section{E. Kesimpulan}

1. Pengelolaan Administrasi pada Pesantren Darul Abror.

Secara umum pengelolaan administrasi khususnya pengelolaan pada perencanan dan pengembangan kurikulum di Pondok Pesantren Daarul Abror sudah lilaksanakan dengan baik. Pengelolaan admisistrasi pengembangan kurikulum bersandar pada institusi atau lembangan yang menangani langsung tentang pendidikan baik BNSP, Kementerian Pendidikan dan Kebudayaan, dan Kementerian Agama yang membidangi Pendidikan Agama dan Keagamaan Islam dan Bidang Pendidikan Madrasah. Lembaga-lembaga tersebut menjadi dasar kebijakan dalam pola penerapan standar pendidikan di pesantren tersebut.

Dalam hal perencanaan lebih lanjut pada tingkat satuan kerja Pondok Pesantren Daarul Abror, melibatkan seluruh kompunen yang ada yang terlibat secara langsung maupun tidak langsung, baik yang berada dalam struktur organisasi kerja seperti, Ketua Yayasan, Kepala Pondok Pesantren, Kepala Madrasah, dan Tenaga Pengajar, maupun yang terlibat secara tidak langsung yang berada diluar struktuk organisasi seperti, Instansi Terkait, Tokoh Pendidikan, Komite Madrasah, Wali siswa/santri, dan siswa itu sendiri.

\footnotetext{
${ }^{20}$ Peraturan Menteri Pendidikan dan Kebudayaan Republik Indonesia Nomor 66, "Standar Penilaian Pendidikan" (2013).
} 
Muatan kurikulum yang dikembangkan juga mengacu pada pola pendidikan moderen. Ini menunjukkan bahwa Pesantren tersebut sudah menyadari tentang kebutuhan dunia pendidikan yang sebenarnya dalam rangka mempersiapkan anak didik atau santrisantri mereka dalam menghadapi kehidupan di jaman nya. Kesadaran akan pola pendidikan yang kekinian tentu akan menjadi daya tarik tersendiri bagi masyarakat dalam memberikan kepercayaan untuk mendidik anak-anak mereka di sebuah lembaga yang menjajikan.

2. Pelaksanaan Pengembangan Kurikulum di Pesantren Darul Abror.

Dalam perkembangannya ilmu kependidikan yang di tuangkan dalam kurikulum selalu berubah menyesuaikan dengan kebutuhan dunia pendidikan itu sendiri, kurikulum yang terus berubah membuat para pendidik harus berpikir keras untuk bisa mengembangkan sehingga membuat pembelajaran lebih efektif

Latar belakang perlunya perubahan kurikulum menurut mentri Pendidikan dan Kebudayaan, Muhammad Nuh bahwa ditengah perubahan zaman. ${ }^{21}$ sistem pendidikan di Indonesia juga harus ikut menyesuaikan. Pengembangan kurikulum 2013 diharapkan mampu menjadi jawaban untuk meningkatkan kemampuan sumber daya manusia dalam menghadapi perubahan dunia. ${ }^{22}$ Disini Kurikulum 2013 juga merupakan lanjutan dari Pengembangan Kurikulum Berbasis Kompetensi yang telah dirintis pada tahun 2004 dengan mencakup kompetensi sikap, pengetahuan, dan keterampilan secara terpadu.

Adapun landasan penyempurna kurikulum 2013 antara lain : (1) Landasan Yuridis, (2) Landasan Filosofis, (3) Landasan Teoritis. ${ }^{23}$

Pengembangan kurikulum didasarkan pada prinsip-prinsip berikut: (1) Kurikulum bukan hanya merupakan sekumpulan daftar mata pelajaran. (2) Kurikulum didasarkan pada standar kompetensi lulusan yang ditetapkan. (3) Kurikulum didasarkan pada model kurikulum berbasis kompetensi. (4) Kurikulum dikembangkan dengan memberikan kesempatan kepada peserta didik untuk mengembangkan perbedaan dalam kemampuan dan minat. (5) dll .

\footnotetext{
${ }^{21}$ Muhammad Nuh, "Kurikulum 2013," Sumber: Http://Www. Kemdiknas. Go. Id, 2013.

${ }^{22}$ Imam Machali, "Kebijakan Perubahan Kurikulum 2013 Dalam Menyongsong Indonesia Emas Tahun 2045," Jurnal Pendidikan Islam 3, no. 1 (2014): 71-94.

${ }^{23}$ Harun Harosid, "Kurikulum 2013 Revisi 2017," Kementerian Pendidikan Nasional Republik Indonesia, 2017.
} 
Struktur kurikulum adalah juga gambaran mengenai penerapan prinsip kurikulum mengenai posisi seorang siswa dalam menyelesaikan pembelajaran di suatu satuan atau jenjang pendidikan. Struktur kurikulum terdiri atas Kompetensi Inti, Mata Pelajaran, Beban Belajar, Kompetensi Dasar. ${ }^{24}$

Dalam hal implementasi dari perencanaan dan pengembangan kurikulum di Pesantren Daarul Abror, sudah terlihat dari pola penerapan pembelajarannya. Dimana para siswa/santri mendapatkan pembelajaran di dalam kelas maupun pengembangan materi di luar kelas dan bahkan pembelajaran untuk bekal kehidupannya di masa yang akan datang atau Life Skill. Implementasi pengembangan kurikulum juga mencakup pembiasaanpembiasaan hidup yang mereka terapkan dari mulai tidur sampai menjelang tidur lagi.

Implementasi pendidikan Agama Islam seperti ini menjadi sangat penting untuk proses pemahaman akan ilmu-ilmu agama Islam yang mereka dapatkan di dalam kelas maupun ilmu-ilmutentang kecakapan hidup lainnya yang mereka bisa dapatkan di dalam lingkungan pondok pesantren. Termasuk penanaman karakter atau akhlak mulia menjadi bagian utama dalam pengembangan kurikulum pendidikan agama Islam di pesantren. Pola hidup sederhana, pola hidup sehat, pola hidup berkebersamaan, pola gotong royong, saling membantu, dan menghargai perbedaan benar-benar menjadi pembiasaan bagi para siswa/santri pondok pesantren.

\footnotetext{
${ }^{24}$ J. R Source: Finch, C.R. and Crunkilton, "Curriculum Development in Career and Technical Education," 1999.
} 
| DWI SAPRIDA RAMAMI, DKK.| Perencanaan dan Pengelolaan Pesantren...

\section{Daftar Pustaka}

66, Peraturan Menteri Pendidikan dan Kebudayaan Republik Indonesia Nomor. Standar Penilaian Pendidikan (2013).

Abidullah. "Penilaian Pembelajaran." https://abibulah.blogspot.com/2013/04/penilaianpembelajaran.html, 2013.

Aulia, Tia. "Stakeholders Pendidikan."

https://huurinien.blogspot.com/2015/09/stakeholder-dalam-pendidikan.html, 2014.

Dhofier, Zamakhsyari. Tradisi Pesantren. 8th ed. Jakarta: LPEES, 2011.

Gani, Dadang. "Kajian Pembelajaran Islam Di Pesantren Modern." https://dadanggani.blogspot.com/2010/04/kajian-pembelajaran-agama-islamdi.html., 2010.

Gunawan, Imam. “Metode Penelitian Kualitatif.” Jakarta: Bumi Aksara, 2013.

Haedari, Amin dan Ishom El -saha. Peningkatan Mutu Perpadu Pesanten Dan Madrasah Diniyah. Jakarta: Diva Pustaka, 2008.

Halim, Abd. Manajemen Pesantren. Pustaka Pesantren, 2005.

Harosid, Harun. “Kurikulum 2013 Revisi 2017.” Kementerian Pendidikan Nasional Republik Indonesia, 2017.

Khamid, Abdul, and Linda Istiroh. "Manajemen Pondok Pesantren Nurul Amal Desa Kenteng Kecamatan Bandungan Kabupaten Semarang," n.d.

Lihin. "Pengertian Pendidikan Moderen," n.d.

Machali, Imam. "Kebijakan Perubahan Kurikulum 2013 Dalam Menyongsong Indonesia Emas Tahun 2045.” Jurnal Pendidikan Islam 3, no. 1 (2014): 71-94.

Muhtifah, Lailial. "Pola Pengembangan Kurikulum Pesantren Kasus Al-Mukhlishin Mempawah Kalimantan Barat." Jurnal Pendidikan Islam UIN Sunan Gunung Djati 27, no. 2 (2012): 203-22.

Nuh, Muhammad. “Kurikulum 2013.” Sumber: Http://Www. Kemdiknas. Go. Id, 2013.

Setiowati, Nur Eka. "Manajemen Pembiayaan Pendidikan Pondok Pesantren Dan Lembaga Pendidikan Terpadu Nurushiddiiq Cirebon." Al-Amwal: Jurnal Ekonomi Dan Perbankan Syari'ah 7, no. 2 (2016).

Source: Finch, C.R. and Crunkilton, J. R. "Curriculum Development in Career and Technical Education," 1999. 
Perencanaan dan Pengelolaan Pesantren... | DWI SAPRIDA RAMAMI, DKK.|

Suparta. Pengantar Teori Dan Aplikasi Pengembangan Kurikulum PAI. 1st ed. Jakarta: Rajawali pers, 2016.

Wahid, K H Abdurrahman. Menggerakkan Tradisi; Esai-Esai Pesantren. LKIS Pelangi Aksara, 2001. 